\title{
RAT ALLOTRANSPLANTATION OF EPIGASTRIC MICROSURGICAL FLAPS: A STUDY OF REJECTION AND THE IMMUNOSUPPRESSIVE EFFECT OF CYCLOSPORIN A
}

Fábio R. Carramaschi, Gilles Landman, Rosangely C. C. Corsi, Luiz P. M. Vana and Marcus C. Ferreira

CARRAMASCHI FR et al. - Rat allotransplantation of epigastric microsurgical flaps: a study of rejection and cyclosporin a immunosuppression effects. Rev. Hosp. Clín. Fac. Med. S. Paulo 55 (1):21-28, 2000.

SUMMARY: The rejection of allotransplantation of epigastric microsurgical flaps and the effect of immunosuppression have been studied in 58 rats. Three sets of experiments were planned: (1) Wistar Furth isogenic donors and receptors (control set); (2) Brown Norway donors and Wistar Furth receptors (rejection set); and (3) Brown Norway donors and Wistar Furth immunosuppressed receptors (cyclosporin A set). Cyclosporin A (10 mg/kg/d) treated rats had a transplantation survival rate of up to 30 days: $83.3 \%$ among isogenic animals and $60 \%$ among allogeneic. There was $100 \%$ rejection by the $9^{\text {th }}$ day after the transplantation in allogeneic non-immunosuppressed rats. Biopsies embedded with historesin were taken from the flap and normal contralateral skin (used as control) on the $3^{\text {rd }}, 7^{\text {th }}, 15^{\text {th }}$, and $30^{\text {th }}$ days after the surgery. A quantitative study of infiltrating lymphocytes in the flaps, with and without cyclosporin A, was done by evaluating the local inflammatory infiltrate. A significant increase in the number of lymphocytes among the rejection and immunosuppressed groups was seen, as compared to the isogenic set. Local lymphocytosis in allogeneic non-immunosuppressed transplantations reached its highest level on the $3^{\text {rd }}$ day after surgery, before gross findings of rejection, which could only be seen by naked eye on the $5^{\text {th }}$ or $6^{\text {th }}$ day. Therefore, we conclude that cyclosporin A is effective in preserving allogenic transplantation in rats. Biopsies of transplanted areas may contribute to earlier diagnosis of the need for immunosuppressive therapy.

DESCRIPTORS: Allotransplantation. Cyclosporin A.

Organs and tissue transplantations have always been one of the alternatives suggested for the correction of congenital acquired diseases ${ }^{16,30}$. However, tissues coming from autogenous donor areas are relatively scarce.

Thus, there are clinical circumstances in which it would be desirable to obtain tissues from donors (alive or dead), as in very large burned areas ${ }^{1,7,8}$, complex oncologic or traumatic tissue loss, and limb reconstruction due to trauma or aplasia ${ }^{11,32}$.

The improvement of skin graft survival with the use of cyclosporin A has already been proved ${ }^{1,2,12,15,19}$. However, attempts at achieving full integration of skin grafts have not always been successful ${ }^{1,9,17,21,23,34}$.
The use of immunosuppressing drugs, usually accompanied by the concurrent adverse side effects, has fewer restrictions with organ transplantations that are essential to the patient's survival. Limb and tissue transplantations, however, have more restraints ${ }^{20}$. Therefore, allogeneic transplantations of tissues and limbs ${ }^{27}$, despite their technical feasibility, have not been done in humans, and research has been limited $^{32}$.

In order to contribute to the study of rejection of cutaneous allotrans-

From the Divison of Plastic Surgery, Hospital das Clínicas, Faculty of Medicine, University of São Paulo. plantations with and without the use of cyclosporin A, we developed an experimental model. Survival indexes and lymphocyte quantitative studies were performed.

\section{MATERIAL AND METHOD}

Fifty-eight epigastric flap microsurgical cutaneous allotransplantations were performed. Three sets of experiments were designed as follows:

- isogenic I (transplantation: Wistar Furth as donors and receptors), used as controls for the surgery effects;

- rejection R (allogenic transplantation: Wistar Furth receptors and 
Brown Norway donors), used to study rejection;

- cyclosporin Ci (allogenic transplantation with cyclosporin A treatment, $10 \mathrm{mg} / \mathrm{kg} /$ day intramuscular, Wistar Furth receptors and Brown Norway donors).

Both the donor and the receptor were anesthetized with intraperitoneal sodium pentobarbital $30 \mathrm{mg} / \mathrm{kg}$ ). A flap from the right lower abdominal skin of each animal was obtained, according to the technique.

A detailed description of gross changes of the skin was recorded during the 30 days following surgery. On the third day after surgery, a microscopic review of the anastomoses was performed.

Biopsy specimens of the flap of the contralateral skin (control) were obtained from groups $I$ and $C i$ on the $3^{\text {rd }}$, $7^{\text {th }}, 15^{\text {th }}$, and $30^{\text {th }}$ days after the surgery, and from $R$ group on the $3^{\text {rd }}$ and $7^{\text {th }}$ postoperative days.

The specimens were prepared in methacrylate historesin and stained with toluidine blue, and are labelled as follows:

$\mathrm{ICo}=$ control skin from the isogenic group;

IT = isogenic group transplantation;

$\mathrm{RCo}=$ control skin from the rejection group;

$\mathrm{RT}=$ rejection group transplantation;

$\mathrm{CiCo}=$ control skin from the cyclosporin group;

$\mathrm{CiT}=$ cyclosporin group transplantation.

The postoperative day when the biopsies were taken was added to the code.

A double-blind study was performed for lymphocyte quantitation in the tissue. Lymphocyte quantitation was performed through comparison of means obtained in 18 fields. A graticule adapted to the ocular (10x) with 50 randomly distributed lines was used, and lymphocytes that were intersected by the lines were counted. Due to the great individual variations, a non-parametric statistical analysis was performed with a Mann-WhitneyWilcoxon test ${ }^{37}$. Statistical significance was declared at $\mathrm{p}<0.05$.

\section{RESULTS}

Among the 58 animals that underwent transplantation, 45 (77.6\%) presented pervious anastomoses when evaluated on the $3^{\text {rd }}$ postoperative day. Thirteen animals $(22.4 \%)$ presented thrombosis in artery, vein, or both near the anastomoses, and therefore these individuals were excluded from the study.

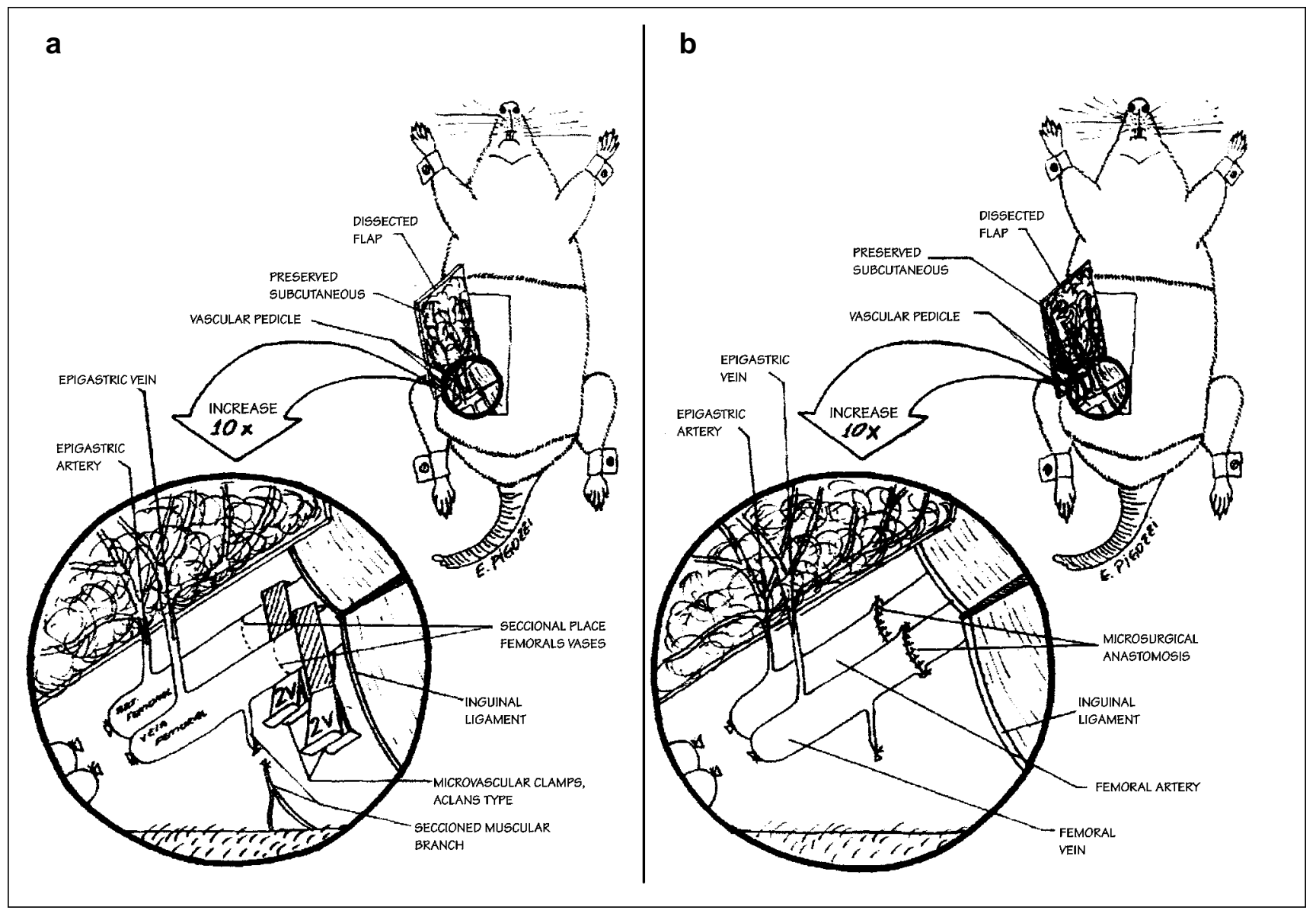

Figure 1 - Illustration of epigastric flap: a - dono rat; b - receptor rat (dissected flap, preserved panniculus adiposus, vascular pediculous). 
Among the 45 remaining rats, 30 survived to the end of the 30 day follow-up period (12 from $I, 8$ from $R$ and 10 from $C i$ group) (Table 1 ).

Daily microscopic analysis of the flaps from $I$ group showed moderate edema, although color and hair development remained similar to the adjacent skin area that had not undergone surgery, other than local moderate edema.

On the 1 st and 2 nd postoperative days, Group $R$ transplantations resembled those of group $I$. Subsequently, local edema was much more intense, and on the $4^{\text {th }}$ or $5^{\text {th }}$ day, hyperemia and local signs of tissue involvement were evident, which evolved from local ulceration and necrosis to full necrosis between the 6 th and 9 th days.

Among the 10 rats from the $C i$ group, $60 \%$ of the flaps survived. Four $(40 \%)$ presented total necrosis at different times, observed on the $10^{\text {th }}, 18^{\text {th }}$, $19^{\text {th }}$, and $24^{\text {th }}$ postoperative days (Table $1)$. These animals showed an intense early edema after surgery $\left(3^{\text {rd }}\right.$ and $4^{\text {th }}$ days after surgery).

Gross examination of rats with 30day graft survival showed significant differences between the three studies sets, group $I=83,3 \%$, group $R=0$ and group $C i=60 \%$.

Figures 2 and 3 are examples of the features observed in the presence and absence of rejection. Microscopic findings are shown on Figs. 4 and 5.

There was a significant difference in the histologic analysis of normal skin and flap biopsies in all postoperative days for groups $R$ and $C i$, and only on the $15^{\text {th }}$ day for $I$ group. Lymphocytes in control skin among the 3 groups were scarce or absent in all studied postoperative days.

We have compared counting of lymphocytes among the different groups for each studied postoperative day. There were statistically significant differences between of groups $I$ and $R$
Table 1 - Analysis of microsurgic cutaneous transplantations survival in the individuals within 30 days

\begin{tabular}{ccccc}
\hline & Group NEC & \% NEC & N NEC & \% N NEC \\
\hline $\mathrm{I}$ & $2 / 12$ & 16.7 & $10 / 12$ & 83.3 \\
$\mathrm{R}$ & $8 / 8$ & 100.0 & $0 / 8$ & 0 \\
$\mathrm{Ci}$ & $4 / 10$ & 40.0 & $6 / 10$ & 60.0 \\
\hline
\end{tabular}

$\mathrm{NEC}=$ necrosis $; \mathrm{N}$ NEC $=$ non necrosis $; \mathrm{R}=$ rejection $; \mathrm{I}=$ isogenic $; \mathrm{Ci}=$ cyclosporin $\mathrm{A}$.

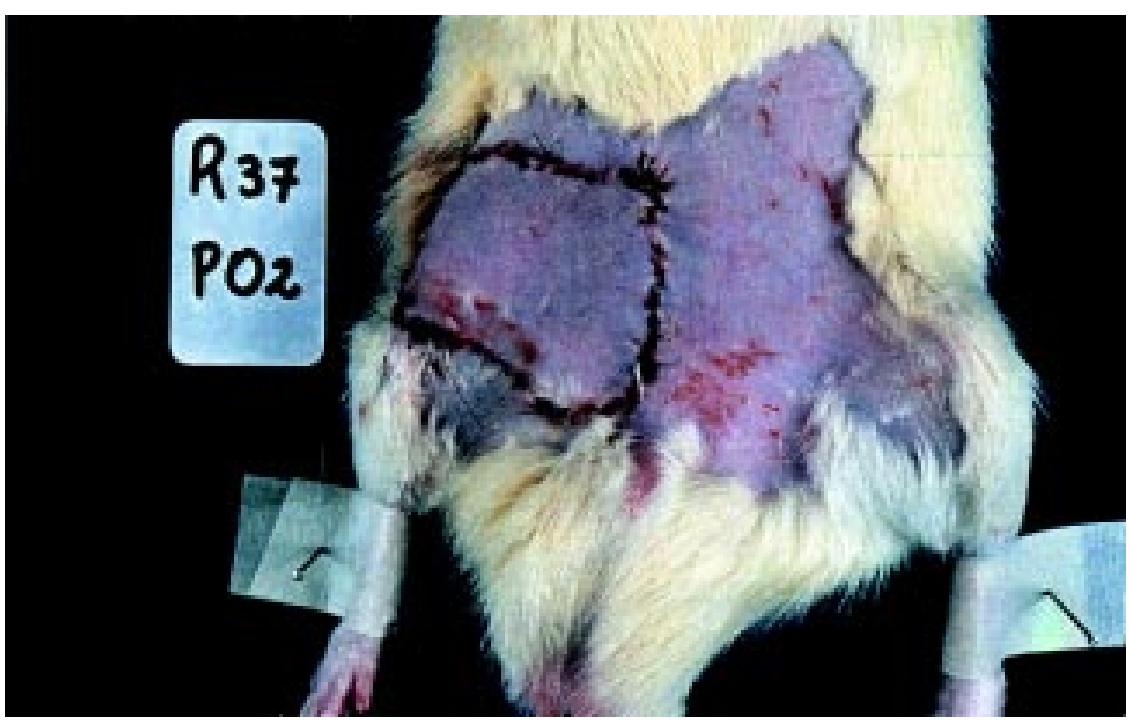

Figure 2 - Epigastric flap without rejection.

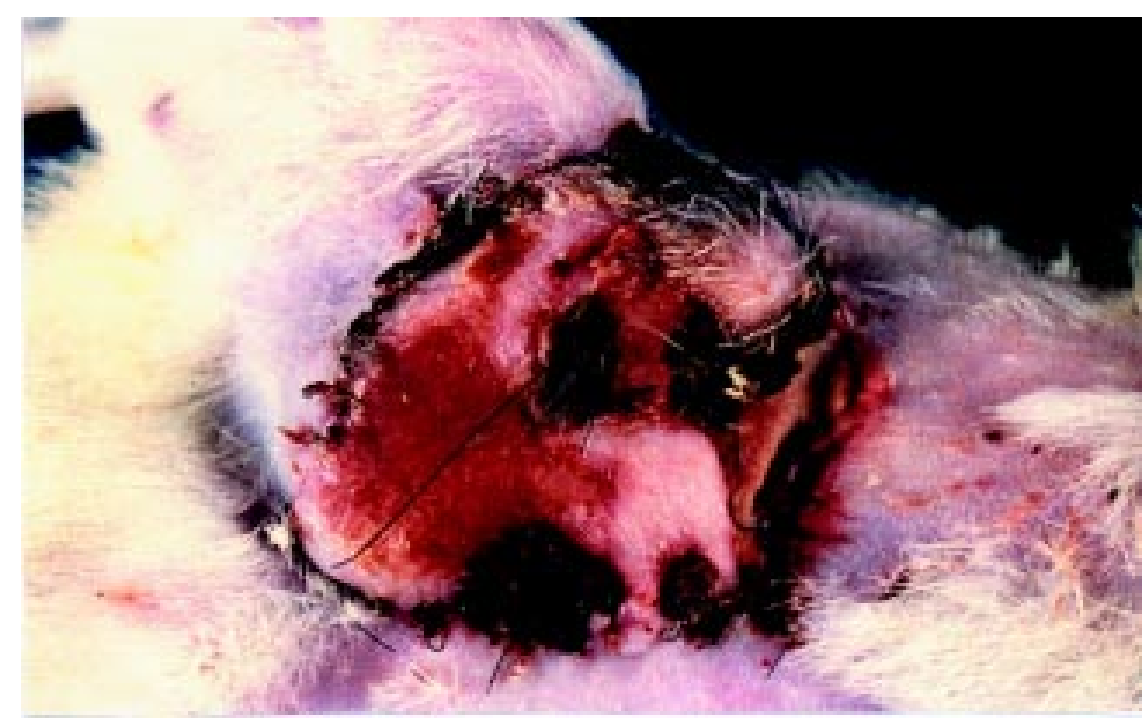

Figure 3 - Epigastric flap with rejection. 


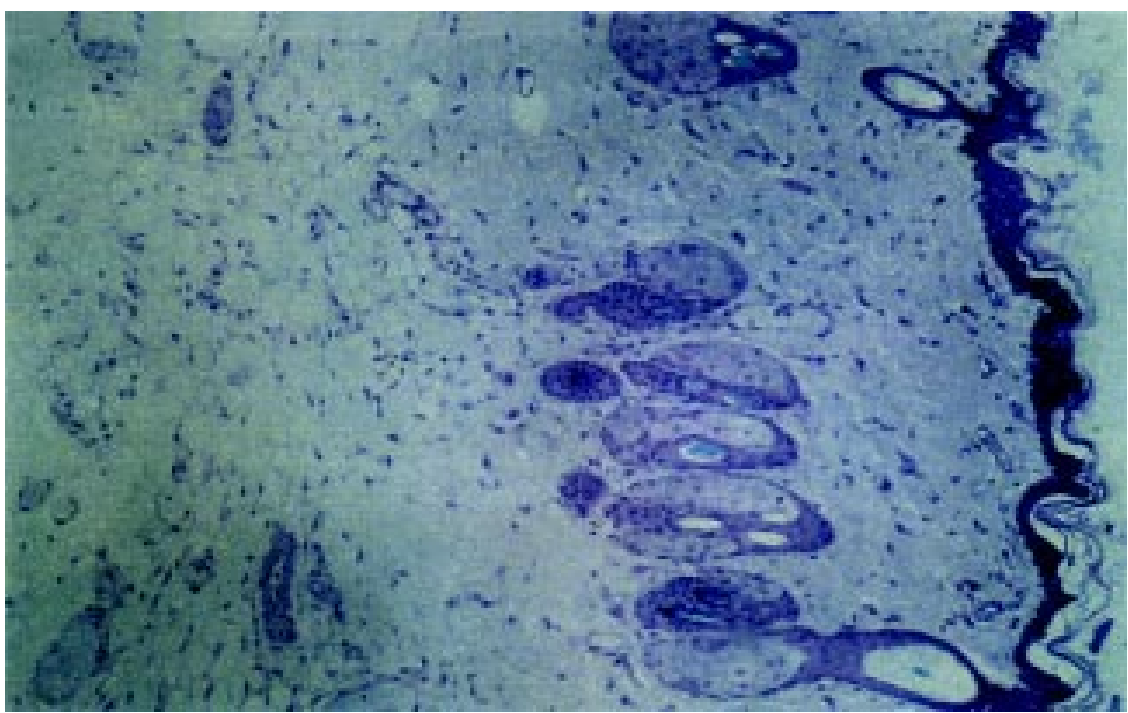

Figure 4 - Histologic slide, with no inflammatory infiltrate, stained with toluidin blue, in the absence of rejection.

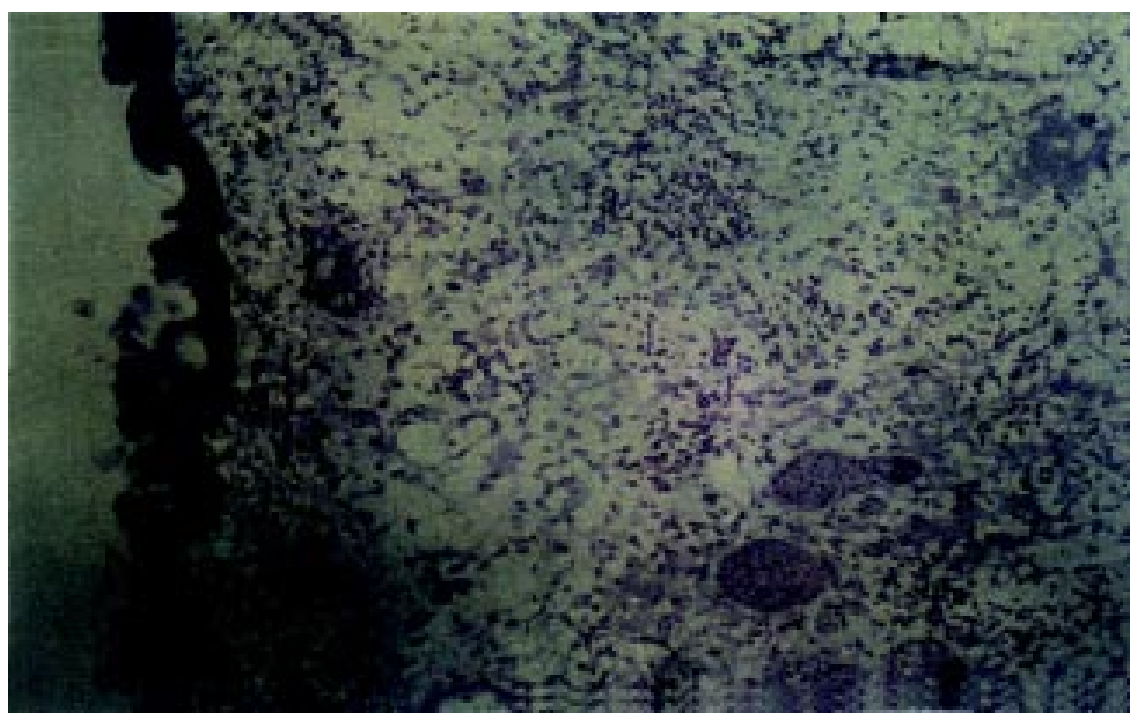

Figure 5 - Histologic slide, with intense inflammatory infiltrate, stained with toluidin blue, in the presence of rejection.

Table 2 - Lymphocyte counting: probality values Mann-Witney-Wilcoxem's non parametric test in the comparison of groups I, $\mathrm{R}$ and $\mathrm{Ci}$ on the $3^{\text {rd }}$ postoperative day.

\begin{tabular}{ccc}
\hline $\begin{array}{c}\text { Group and POday } \\
\text { Postoperative day }\end{array}$ & IT-3 & CiTY-3 \\
\hline CiT & 0.199 & \\
RT-3 & $0.013^{*}$ & - \\
\hline
\end{tabular}

$(-)=$ comparison not performed

* significant values when $\mathrm{p} £ 0.05$

$\mathrm{CiT}=$ cyclosporin set transplantation

$\mathrm{RT}=$ rejection set transplantation on the $3^{\text {rd }}$ postoperative day (Table 2 ), and between the controls of $I$ and $C i$ groups on the $7^{\text {th }}$ day (Table 3 ).

\section{DISCUSSION}

The feasibility of a future use of allogeneic $60 \%$ tissue and limb transplantations in reconstructive plastic surgery ${ }^{11,14}$ justifies the development of an experimental model for the systematic study of skin rejection.

A $77.6 \%$ vascular permeability was obtained-a satisfactory rate, according to the literature, in which 75 to $90 \%$ permeability has been $\operatorname{seen}^{26,28,29,33}$.

The isogenic flap survival rate, $83.3 \%$, was considered the basal line for evaluation of the other sets of experiments.

Mortality, although high (33.3\%), occurred in different postoperative phases before we observed any gross sign of rejection. Therefore, we were able to evaluate transplantation for 30 days among the remaining 30 animals without having to consider mortality as a variant for the rejection factor.

In group $R$, flap loss occurred in $100 \%$ of the cases after 6 to 8 days, a rate which is significantly different from group $I$ (Table 1). Gross findings for group $R$ clearly characterized a rejection delay occurring according to the reported literature ${ }^{22,31}$. However, rejection occurred earlier than the ones observed in organ transplantations, such as heart ${ }^{4,13,18}$, kidney ${ }^{25,35,36}$, and small bowel rejection in rats ${ }^{24}$. Similarly in the $C i$ group, rejection occurred earlier than for other tissues and organs, even with the use of cyclosporin $\mathrm{A}^{22}$. A higher skin antigenicity may be the reason why flaps are rejected earlier than other tissues, although the mechanism is not yet fully understood ${ }^{5,6,10}$.

A 30-day follow-up survival was observed in six flaps from $\mathrm{Ci}$ Group. Four flap losses occurred on the 10th, 
Table 3 - Lymphocyte counting: probality values Mann-Witney-Wilcoxem's non parametric test in the comparison of groups $I, R$ and $C i$ on the 7th postoperative day.

\begin{tabular}{ccc}
\hline $\begin{array}{c}\text { Group and POday } \\
\text { Postoperative day }\end{array}$ & $\begin{array}{c}\text { ICo-7 } \\
\text { Isogenic set control }\end{array}$ & $\begin{array}{c}\text { CiCo-7 } \\
\text { Cyclosporin set control }\end{array}$ \\
\hline$C i$ Co-7 & $7.919 \times 10^{-3}$ & - \\
$R$ Co-7 & $0.693^{*}$ & 0.476 \\
\hline
\end{tabular}

$(-)=$ comparison not performed

* significant values when $\mathrm{p} £ 0.05$

$R \mathrm{co}=$ rejection set control

17 th, $18^{\text {th }}$, and 23 rd postoperative days. Therefore cyclosporin A was effective, increasing survival rates of cutaneous allogeneic transplantations.

Third day post-op biopsy lymphocyte counts had significant differences between the allogenic non-treated transplantation group $(R)$ and isogenic transplantation group (I) (Table 2).

Comparison between gross rejection findings and lymphocytic infiltration showed that lymphocyte infiltration precedes gross signs of necrosis. The lymphocyte infiltration occurred on the $3^{\text {rd }}$ day post operative, whereas symptoms of gross rejection were first seen on the $6^{\text {th }}$ post-operative day. Therefore, as reported in the literature, biopsy specimens must be taken and examined for early signs of rejection in order to prevent full necrosis of the transplanted tissue.
In group $C i$, there was a significant difference in lymphocytes counted between transplanted and control sets. Thus, it was observed that even though cyclosporin A had a satisfactory action on rejection control, its use did not result in a decrease in the number of "in situ" lymphocytes with the method used.

Based on what was found, the authors continued researching immunohistochemical methods with monoclonal antibodies ${ }^{3,6,22}$ to identify the "in situ" lymphocytes found in this experimental model.

\section{CONCLUSION}

1) The rate of survival of epigastric flap used as microsurgical cutaneous transplantation to isogenic Wistar Furth rats was $83.3 \%$ up to 30 days, confirm- ing the efficacy of the adopted experimental model.

2) In our experiments, when flaps of Brown-Norway rats are transplanted to Wistar-Furth receptors, a $100 \%$ rejection rate in non-immunosuppressed transplantation occurs before the $9^{\text {th }}$ postoperative day.

3) Cyclosporin A immunosuppression $(10 \mathrm{mg} / \mathrm{kg} / \mathrm{d})$ increased the allogeneic transplantation success up to 30 days post-operation.

4) Non-immunosuppressed allotransplantation shows a significant increase of infiltrating lymphocytes on the $3^{\text {rd }}$ day as compared to isogenic transplantation. Symptoms of gross rejection findings are preceded by lymphocytic infiltration.

5) Despite the use of cyclosporin A, an increased rate in the lymphocytic infiltration was seen, as compared to the control isogenic transplantation group. Therefore, it may be assumed that cyclosporin A induces rejection delay, blocking the cytotoxic cell effect or humoral immune reaction, even though cell migration does occur.

6) The use of plastic embedded tissue enables a better characterization of the histological findings of rejection.

Further studies with immunohistochemical cell sorting are ongoing in our laboratories to enhance our knowledge in this field.
CARRAMASCHI FR e col. - Rejeição e efeitos da ciclosporina nos transplantes cutâneos alógenos microcirúrgicos em ratos. Rev. Hosp. Clín Fac Med. S. Paulo 55(1):21-28, 2000.
Os efeitos da rejeição e da imunossupressão com ciclosporina A em retalhos epigástricos utilizados como transplantes cutâneos alógenos microcirúrgicos, foram estudados em 58 ratos, distribuídos em três grupos:
Wistar-Furth isogênicos doadores e receptores; e Brown-Norway doadores e Wistar-Furth receptores, imunossuprimidos com cicloporina $\mathrm{A}(10 \mathrm{mg} / \mathrm{kg} / \mathrm{dia})$. Biópsias dos retalhos e da pele normal contralateral utilizadas 
como contrôle foram colhidas no terceiro, sétimo, $15^{\circ}$ e $30^{\circ}$ dias pós transplante. As biópsias foram preparadas em historesina, e coradas em azul de toluidina, para avaliação do infiltrado inflamatório local, permitindo estudo quantitativo dos linfócitos infiltrantes nos retalhos. $\mathrm{O}$ modelo revelou-se eficiente, obtendo-se sobrevivência dos transplantes por 30 dias, de 83,3\% entre animais isogênicos, e de $60 \%$ nos alogênicos sob ação da ciclosporina A. Em ratos alogênicos não imunossuprimidos houve $100 \%$ de rejeição dos retalhos, até o nono dia pós-operatório. Nos transplantes desses animais, verificou-se aumento significativo do número de linfócitos infiltrantes no terceiro dia, quando comparados aos ratos isogênicos. A linfocitose observada antecedeu os achados macroscópicos da rejeição, verificados apenas no quinto ou sexto dias.

DESCRITORES: Transplante de tecidos. Ciclosporinas.

\section{REFERENCES}

1. ACHAUER BM, HEWITT CW, BLACK KS et al. - Long-term skin allograft survival after short-term cyclosporin treatment in a patient with massive burns. Lancet 1986;1:14.

2. ACHAUER BM, HEWITT CW, BLACK KS et al. - Cyclosporine prolongs skin allografts in a rat burn model. Transplant Proc 1985;15:3073-3076.

3. BAIN JR, MACKINNON SE, HUDSON AR et al. - The peripheral nerve allograft: a dose-response curve in the rat immunosuppressed with cyclosporin A. Plast Reconst Surg 1988;82:447-455.

3. BAIN JR, MACKINNON SE, HUDSON AR et al. - The peripheral nerve allograft in the primate immunosuppressed with cyclosporin A: I. Histologic and electrophysiologic assessment. Plast Reconstr Surg1992;90:1036-1046.

4. BHAN AK, MIHM MC \& DVORAK HF - T cell subsets in allograft rejection. In situ characterization of $\mathrm{T}$ cell subsets in human skin allografts by the use of monoclonal antibodies. J Immunol 1982;129:1578-1583.

5. BIRINYI LK, BALDWIN WM \& TILNEY NL - Differential effects of heterologous antisera on the survival of cardiac and skin allografts in rats. Transplantation 1981;32:336-338.

6. BLACK KS, HEWITT CW \& HENSON LE - Cyclosporine-induced long-term allograft survival and its potential in posttrauma tissue replacement. J Burn Care Rehabil 1987;8:531-535.

7. BLACK KS, HEWITT CW, SMELSER S et al. - Cyclosporine and skin allografts for the treatment of thermal injury. II. Development of an experimental massive third-degree burn model demonstrating extensive graft survival. Transplantation 1988;4513-16.

8. BLACK KS, PATEL MP, PATEL AP et al. Mechanisms of site-specific immunosuppression.Transplant Proc 1991;23:120-121.

10. BOREL JF - Cyclosporin-A: present experimental status. Transplant Proc 1981;13:344-348.
11. BOREL JF - Cyclosporine: historical perspectives. Transplant Proc $1983 ; \mathbf{1 5}: 2219-2229$.

12. BOREL JF, FEURER C \& GUBLER HU - Biological effects of cyclosporin A: a new antilymphocytic agent. Agents Actions 1976;6:468-475.

13. BOREL JF, FEURER C, MAGNÉE C et al. - Effects of the new antilymphocytic peptide cyclosporin A in animals. Immunology 1977;32:1017-1025.

14. BOS JD, ZONNEVELD I, DAS PK et al. - The skin immune system (SIS): distribution and immunophenotype of lymphocyte subpopulations in normal human skin. J Invest Dermatol 1987;88:569-573.

15. BUNCKE HJ, DANILLER AI, SCHULZ WP et al - The fate of autogenous whole joints transplanted by microvascular anastomoses. Plast Reconstr Surg 1967;3:333-341.

16. BUNCKE HJ \& SCHULZ WP - Experimental digital amputation and reimplantation. Plast Reconstr Surg 1965;36:62-70.

17. BUNCKE HJ \& SCHULZ WP - Total ear reimplantation in the rabbit utilizing microminiature vascular anastomoses. Br J Plast Surg 1966;19:15-22.

18. BURKE JF, MAY JW, ALBRIGHT N et al. - Russel PS. Temporary skin transplantation and immunosuppression for extensive burns. N Engl J Med 1974;290:269-271.

19. BURKE JF, QUINBY WC, BONDOC CC et al. - Immunosuppression and temporary skin transplantation in the treatment of massive third degree burns. Ann Surg 1975;182:183-197.

20. COSIMI AB, SHIELD CF, PETERS C et al. - Prolongation of allograft survival by cyclosporin A. Surg Forum 1979;30:287-289.

21. DUPUY P, BAGOT M, MICHEL L et al. - Cyclosporin A inhibits the antigen-presenting functions of freshly isolated human Langerhans cells in vitro. J Invest Dermatol 1991;96:408-413. 
22. EGERSZEGI EP, SAMULACK DD \& DANIEL RK - Experimental models in primates for reconstructive surgery utilizing tissue transplants. Ann Plast Surg 1984;13:423-430.

23 FIRST international workshop on alloantigenic systems in the rat: report. Transplant Proc 1978;10:271-285.

24. FREEMAN JS \& STEINMULLER D - Acute rejection of skin and heart allografts in rats matched at the major rat histocompatibility locus. Transplantation 1969;8:530-533.

25. FUJINO T, HARASHINA T \& AOYAGI F - Reconstruction for aplasia of the breast and pectoral region by microvascular transfer of a free flap from the buttock. Plast Reconstr Surg 1975;56:178-181.

26- FUJINO T, TANINO R \& SUGIMOTO C - Microvascular transfer of free deltopectoral dermal-fat flap. Plast Reconstr Surg 1975;55:428-434.

27. FURNAS DW, BLACK KS \& HEWITT CW - Cyclosporine and long-term survival of composite tissue allografts (limb transplants) in rats (with historical notes on the role of plastic surgeons in allotransplantation). Transplant Proc 1983;15:3063-3068.

28. GILL TJ, CRAMER DV \& KUNZ HW - The major histocompatibility complex - Comparision in the mouse, man, and the rat. A review. Am J Pathol 1978;90:737-777.

29. GNUDI MT et al. - The sympathetic slave. In: GNUDI MT - The life and Times of Gaspare Tagliacozzi. Los Angeles, Zeitlin Brugge 1976. p.285-286. Apud - FURNAS DW et al. ${ }^{27}$

30. GRATWOHL A, FORSTER I \& SPECK B - Skin grafts in rabbits with cyclosporin A. Absence of induction of tolerance and untoward side effects. Transplantation 1981;31:136-138.

31. GULATI AK \& ZALEWSKI AA - Muscle allograft survival after cyclosporin A immunosuppression. Exp Neurol 1982;77:378-385.

32. GUNDLACH M, OLUWOLE S, D'AGATI V et al. - The role of passenger leukocytes in the immunogenicity of intestinal and cardiac allografts in the rat. Transplant Proc 1992;24:1131-1132.

33. HARASHINA T, SAWADA Y \& WATANABE S - The relationship between venous occlusion time in island flaps and flap survivals. Plast Reconstr Surg 1977;60:92-95.

34. HARII K \& OHMORI K - Free groin flaps in children. Plast Reconstr Surg 1975;55:588-592.

35. INNIS PC, RANDOLPH MA, PASKERT JP et al. - Vascularized bone allografts: in vitro assessment of cell-mediated and humoral responses. Plast Reconstr Surg 1991; 87: 315-325.

36. KIM SK, AZIZ S, OYER P et al. - Use of cyclosporin A in allotransplantation of rat limbs. Ann Plast Surg 1984;12:249-255.

37. KUROKI H, ISHIDA O, DAISAKU H et al. - Morphological and immunological analysis of rats with long-term-surviving limb allografts induced by a short course of FK 506 or cyclosporine. Transplant Proc 1991; 23:516-520.

38. LAI CS, WESSELER TA, ALEXANDER JW et al. - Long-term survival of skin allografts in rats treated with topical cyclosporine. Transplantation 1987; 44:83-87.

39. LEE WP, RANDOLPH MA, YAREMCHUK MJ et al. - The effect of graft and donor irradiation on survival of vascularized bone allografts. Orthop Transplant 1988;12:480.
40. LEE WP, YAREMCHUK MJ, PAN Y - Relative antigenicity of components of a vascularized limb allograft. Plast Reconstr Surg 1991;87:401-411.

41. LEMS SPM, CAPEL JA \& KOENE RA - Rejection of long-surviving mouse skin allografts after withdrawal of Cyclosporin A therapy. Transplant Proc 1980;12:283-286.

42. MALT RA \& MCKHANN CF - Replantation of severed arms. JAMA. 1964;189:716-722.

43. MANSON PN, NARAYAN KK IM J, BULKLEY GB et al. - Improved survival in free skin flap transfers in rats. Surgery 1985;99:211215 .

44. MANTEL N - Evaluation of survival data and two new rank order statistics arising in its consideration. Cancer Chemother Rep 1966;50:163-170.

45. MARTIN DC, HEWITT CW, BLACK KS et al. - Extensive prolongation of rat renal allograft survival following donor or nonspecific transfusions and concomitant immunosuppressant. Transplantation 1987;43:790-794.

46. MCCARTY JG - Plastic Surgery - General Principles. New York, Saunders 1990. v.1-9.

47. MURRAY JE, TILNEY NL \& WILSON RE - Renal Transplantation: a twenty-five year experience. Ann Surg 1976;184:565-573.

48. PARSA FD \& SPIRA M - Evaluation of anastomotic techniques in the experimental transfer of free skin flaps. Plast Reconstr Surg 1979;63:696-699.

49. PASKERT JP, YAREMCHUK MJ \& RANDOLPH MA - The Role of cyclosporin in prolonging survival in vascularized bone allografts. Plast Reconstr Surg. 1987;80:240-247.

50. PORTER B \& LANCE EM - Limb and joint transplantation. Clin Orthop 1974;104:249-274.

51. RUBY LK, GREENE M, RISITANO G et al. - Experience with epigastric free flap transfer in the rat: technique and results. Microsurgery 1984;5:102-104.

52. SALYER KE \& KYGER ER - Studies in rats of survival of composite homotransplants of skin and subcutaneous tissue, with microvascular anastomoses. Plast Reconstr Surg 1973;51(6):672681 .

53. SNYDER CC, KNOWLES RP, MAYER PW et al. - Extremity replantation. Plast Reconstr Surg 1960;26:251-263.

54. SOBRADO L, POLLAK R, ROBICHAUX WH et al. - The survival and nature of the immune response to soft-tissue and compositetissue allografts in rats treated with low-dose cyclosporine. Transplantation 1990;50:381-385.

55. TAN CM, YAREMCHUK MJ, RANDOLPH MA et al. - Vascularized muscle allografts and the role of cyclosporine. Plast Reconstr Surg 1991;87:412-418.

56. TILNEY NL \& KUPIEC-WEGLINSKI JW - The biology of acute transplant rejection. Ann Surg 1991;214:98-106.

57. TOWPIK E, KUPIEC-WEGLINSKI JW \& TILNEY NL - The potential use of cyclosporine in reconstructive surgery. Plast Reconstr Surg 1985;76:312-322. 
58. WERKER PM, KON M, GREEN C et al. - Survival characteristics of the epigastric free flap in da-rats. Microsurgery 1992;13:67-71.

59. WHITE DJ, ROLLES K, OTTAWA T et al. - Cyclosporin-A-induced long-term survival of fully incompatible skin and heart grafts in rats. Transplant Proc 1980;12:261-265.

6. WHITE E \& HILDEMANN WH - Allografts in genetically defined rats: difference in survival between kidney and skin. Science 1968;162:1293-1295.

61. WHITE E, HILDEMANN WH \& MULLEN Y. Chronic kidney allograft reactions in rats. Transplantation 1969;8:602-617.
62. WRAY R.C, MATHES SM, YOUNG VL et al. - Free vascularized whole-joint transplants with ununited epiphyses. Plast Reconst Surg 1981;67:519-525.

63. YAREMCHUK MJ, NETTELBLAD H \& RANDOLPH MA Vascularized bone allograft transplantation in a genetically defined rat model. Plast Reconstr Surg 1985;75:355-362.

64. YAREMCHUK MJ, SEDACCA T, SCHILLER AL et al. - Vascular knee allograft transplantation in a rabbit model. Plast Reconstr Surg 1983;71:461-471.

Received for publication on the 22/03/00 